\title{
Lateral
}

Journal of the Cultural Studies Association

\section{Review of Tehrangeles Dreaming: Intimacy and Imagination in Southern California Iranian Pop Music by Farzaneh Hemmasi (Duke Press)}

by Siavash Rokni । Book Reviews, Issue 10.1 (Spring 2021)

\begin{abstract}
Tehrangeles Dreaming is the first book about the Tehrangeles music industry, that is, the Iranian diaspora music industry brought to life by the expatriate Iranian artists and music producers who settled in Los Angeles and Southern California after the 1979 Iranian revolution. Farzaneh Hemmasi uses an ethnographic approach in combination with an analysis of diaspora media discourse in order to "examine expatriate imaginations of influence on, and intimacy with, their global Iranian audiences" (26). At its core, the book deals with the imagining and reimagining of Iranian identity by the artistic community that creates music and media content for Iranians in Iran and across the world.
\end{abstract}

KEYWORDS diaspora, ethnomusicology, Iran, Iranian Americans, Los Angeles, music

Tehrangeles Dreaming: Intimacy and Imagination in Southern California Iranian Pop Music Studies. By Farzaneh Hemmasi. Duke University Press 2020, 246 pp.

(paperback) IBSN 978-1-4780-0836-1. US List: \$26.95.

In one of his first speeches to Iranian radio employees after the 1979 revolution, Ayatollah Rouhollah Khomeini linked music to the consumption of opium and banned the public playing, selling, and distribution of music in the country.- Through the 1980s, most music genres were interpreted as sinful and not in alignment with the values of the new system of governance based on Shari'a law. This left many Iranian musicians and producers with little choice but to leave their profession or the country. Many chose the latter and joined forces in Southern California to start a new music industry known as Tehrangeles, a portmanteau that connects the cities of Tehran and Los Angeles.

Tehrangeles Dreaming is the first book dedicated to understanding this music industry as a cultural phenomenon. The book uses extensive ethnographic field studies alongside diaspora media analysis to paint a picture of the way Iranian identity is imagined and communicated by different actors in this music scene. I see this book as a continued lineage of many scholars, mostly women, who have shown us the importance of studying Iranian popular music in understanding Iranian contemporary culture and its politics. Thus, Hemmasi's book is as much a contribution in the field of Iranian diaspora studies ${ }^{2}$ as it is in the field of Iranian popular music studies. 
The book begins with an introductory chapter that historicizes and contextualizes the rise of the popular music industry in Iran before the revolution. In it, we learn about the "golden age" of Iranian popular music (between the 1950s and 1970s), the changes that followed the Iranian revolution in 1979, and the rise of Tehrangeles music industry in Southern California. The chapter then looks at Tehrangeles and the negative discourse and stereotypes associated with the place, the people who live there, and the artists who work in its music industry. In doing so, it looks past the stereotypes, clarifies terminologies that are used in the book, and emphasizes the significance of research on this industry.

The first and second chapters contextualize the study by looking at the music and the main actors who helped shape it. In the first chapter, the dance rhythm largely associated with Persian pop music, the shesh o hasht (6/8) or Dambuli, is first studied from a technical standpoint. -3 Hemmasi then explores the discourses and politics surrounding this popular rhythm, which was banned in domestic music production in Iran for over twenty years as it was incorporated into Tehrangeles music and "became associated with Tehrangeles itself" (30). The second chapter explores the lives and works of four figures who kick-started the Tehrangeles music industry and offers a "layered, ambivalent relationship to legacy, history, and heritage" (96). It details Hemmasi's encounters with music producer Manouchehr Bibiyan and reviews his contributions to Iranian pop music before and after the revolution. It continues with an analysis of the artist Shahram Shabpareh and his career as the "icon of happiness" (84). It concludes by examining the rise and fall of Vartan Avenssian and Jahangir Tabrei's Taraneh label, as their main source of income, selling cassettes and CDs, slowly became obsolete with the advent of music digitization. The chapter provides significant insight into the roots of the Tehrangeles music scene and provides an invaluable analysis about the motivation, aspirations, and dreams of those who founded it.

The third chapter examines three performers who deal with the "unintended consequences of their Tehrangeles careers" (100). This includes dancer turned fitness instructor, Mohammad Khordadian, the titular fictional Los Angeles cabaret singer in the film Maxx, and the female vocalist Shahrzad Sepanlou. Hemmasi's choice of cases, particularly the inclusion of a fictional character alongside real artists, risks the coherence of this chapter. The chapter looks at Maxx and Khordadian together as they both treat the subject of return to Iran. While Maxx portrays an imaginary case of what would happen if a sexually ambiguous male los anjelesi performer returns to the country, Khordadian's story is a real case of an openly gay Iranian man who returned to Iran, was arrested, and was tried for his cultural activities abroad. The chapter concludes with an analysis of the Iranian singer Sepanlou and shows how she deals with the "challenges of navigating her emplacement in layered American, Iranian and diasporic cultural fields" (120).

The last two chapters of the book examine the lives and legacies of two of the biggest stars of Iranian pop music, Faegheh Atashin (whose stage name is Googoosh) and Dariush Eghbali. It attends to their career histories, music, politics, and current activities in the diaspora media. By law, solo female singers are not allowed to sing publicly in Iran. As an Iranian female singer who stayed in the country after the revolution for twenty years, Googoosh's silence became the metaphor of the silencing of female voices in the country. Hemmasi tends to this idea by investigating how Googoosh recreated herself as an expatriate singer when she left Iran and restarted her career abroad. Through the exploration of her music videos, lyrics, and media activities, Hemmasi shows how Googoosh's "metaphorical language of voice" (151) becomes an important part of her 
image as a person who gives voice to history, performs silence, and becomes "Mother Iran" (144). The fourth chapter also examines the life and works of singer Dariush Eghbali. Known as the Sultan of Sadness for his melancholic music, Dariush is respected by many for not only his music but also his political stance against both the Pahlavi government as well as the Islamic Republic. The chapter examines this past and shows how Dariush reinvented himself as an activist and a humanitarian celebrity following his battles with opium and heroin use for decades. Having made his struggle with addiction and recovery part of his public persona, he openly discusses his challenges with addiction on satellite television and has developed the Ayeneh (Mirror) Foundation as a way to "address Iranians' 'social maladies' - especially addiction" (155). By reiterating how Dariush brought "the tenets of NA-the Twelve Steps, the slogans, and the practice of witnessing recovery -into the Persian language and broadcast them on satellite television," (182) the chapter shows how Dariush used his previous experiences to advocate for others going through recovery.

Hemmasi's book is an invaluable contribution to the study of Iranian popular culture. As Hemmasi has mentioned in a recent podcast interview, popular music analysis has mostly been ignored by Iranian scholars due to the concentration of literature on Persian art music. $\frac{4}{4}$ Thus, this book is a breath of fresh air and it is very insightful for those who are interested in understanding Iranian popular culture as well as Iranian diaspora media practices. Hemmasi is a truly powerful narrator in her ethnographic work and she provides a profoundly deep and pointed analysis of the history, activities, and imaginations of the Tehrangeles music industry and its scene. This book is a welcomed addition to the study of the Iranian popular music and to the development of the Iranian popular music studies.

\section{Notes}

1. Nahid Siamdoust, Soundtrack of the Revolution: The Politics of Music in Iran (Stanford, CA: Stanford University Press, 2017).

2. Ida Yalzadeh, "Review of Tehrangeles Dreaming: Intimacy and Imagination in Southern California's Iranian Pop Music," Jadaliyya, June 23, 2020, https://www.jadaliyya.com/Details/41329 < https://www.jadaliyya.com/Details/41329>

3. This rhythm is different from the Western $6 / 8$ as the first beat grouping is formulated as an eighth note followed by two sixteenth notes and another eighth note while the second grouping consists of an eighth note followed by a quarter note. The best representation of this rhythm in classical music can be found in the rhythmic pattern of the first measure of the third movement of Otar Taktakishvili's Sonata for Flute and Piano in C Major. ?

4. Farzaneh Hemmasi, "Tehrangeles Dreaming Intimacy and Imagination in Southern California's Iranian Pop Music," Oct 12, 2020, podcast hosted by Aaron M. Hagler, New Books Network, https://newbooksnetwork.com/farzaneh-hemmasi-tehrangeles-dreaming-intimacy-andimagination-in-southern-californias-iranian-pop-music-duke-up-2020 < https://newbooksnetwork.com/farzaneh-hemmasi-tehrangeles-dreaming-intimacy-andimagination-in-southern-californias-iranian-pop-music-duke-up-2020>. ?

\section{Author Information}




\section{Siavash Rokni}

Siavash Rokni is a teacher, researcher, translator, editor, musician, and doctoral candidate in Communication at the Université de Québec à Montreal (UQÀM). $\mathrm{He}$ is the winner of an FRQSC doctoral bursary and FARE scholarship. His Master's thesis focused on networked protesting crowds during the 2009 green movement in Iran, and his $\mathrm{PhD}$ research focuses on the rise of the Talfiqi music genre in the post-Iranian-revolution music scene. Siavash has published articles in English and French on various subjects including social movement theory, academic creativity, and music. He has been the guest editor for Commposite and Stream, and he has translated multiple academic articles from French to English. Siavash is a classical flutist, jazz saxophonist, and composer of ensemble music.

View all of Siavash Rokni's articles.

\section{Article details}

Siavash Rokni, "Review of Tehrangeles Dreaming: Intimacy and Imagination in Southern California Iranian Pop Music by Farzaneh Hemmasi (Duke Press)," Lateral 10.1 (2021).

https://doi.org/10.25158/L10.1.28

This content is licensed under a Creative Commons Attribution-NonCommercial 4.0 International License. Copyright is retained by authors.

Lateral is the peer-reviewed, open access journal of the Cultural Studies Association.

ISSN 2469-4053 